\title{
The Impact of Vegetation on Archaeological Sites in the Low Arctic in Light of Climate Change
}

\author{
Henning Matthiesen, ${ }^{1,2}$ Rasmus Fenger-Nielsen, ${ }^{1,3}$ Hans Harmsen, ${ }^{4}$ Christian Koch Madsen ${ }^{4}$ and Jørgen Hollesen ${ }^{1}$
}

(Received 7 June 2019; accepted in revised form 12 November 2019)

\begin{abstract}
Vegetation is changing across the Arctic in response to increasing temperatures, which may influence archaeological sites in the region. At the moment, very little is known about how different plant species influence archaeological remains. In this study we visited 14 archaeological sites stretching across a climatic gradient from the outer coast to the inner fjords in the Nuuk Fjord area of West Greenland to assess the impact of vegetation growth on archaeological preservation. Examination of the physical disturbance of archaeological layers and materials by roots from different plant species showed that horsetail (Equisetum arvense) was particularly destructive because of its deep penetrating rhizomes and ubiquity across the study area. Willow (Salix glauca) also caused physical disturbance due to a dense root network, but its roots were mainly found in the upper $30 \mathrm{~cm}$ of the soil. Focus was also given to the impact from vegetation on the visibility of sites, where growth of willow was found be the main problem, especially in the inner fjords. Historic descriptions and aerial photographs from the sites show that shrub growth was already widespread in the region by the 1930 s, but photos of some of the sites investigated show that the willow shrubs are significantly taller today, which has decreased the visibility of site features. The impact from horsetail and willow on archaeological sites may be mitigated using geotextiles and grazing by livestock, but both methods require further studies before being implemented in the study area.
\end{abstract}

Key words: vegetation; Low Arctic; archaeological sites; root damage; visibility; Nuuk Fjord

RÉSUMÉ. À la grandeur de l'Arctique, la végétation change en réaction aux températures à la hausse, ce qui peut exercer une influence sur les sites archéologiques de la région. En ce moment, on en sait peu sur la manière dont les différentes espèces végétales influencent les restes archéologiques. Dans le cadre de cette étude, nous avons visité 14 sites archéologiques répartis sur un gradient climatique allant de la zone côtière extérieure aux fjords intérieurs de la région du fjord de Nuuk, dans l'ouest du Groenland, afin d'évaluer l'incidence de la croissance de la végétation sur la préservation archéologique. L'examen de la perturbation physique des couches et du matériel archéologiques au moyen des racines de différentes espèces végétales a permis de constater que la prêle (Equisetum arvense) jouait un rôle particulièrement destructeur en raison de ses rhizomes profonds et omniprésents dans toute la zone étudiée. Le saule (Salix glauca) entraîne aussi des perturbations physiques en raison de son réseau de racines denses, bien que ses racines se trouvent principalement dans la couche supérieure de sol de $30 \mathrm{~cm}$. Nous avons aussi accordé de l'importance à l'incidence de la végétation sur la visibilité des sites, ce qui a permis de conclure que la croissance du saule constituait le problème principal, surtout dans la zone intérieure des fjords. Les descriptions historiques et les photographies aériennes des sites montrent que la croissance d'arbustes était déjà répandue dans la région dans les années 1930, bien que certaines photos des sites étudiés permettent de comprendre que les saules arbustifs sont beaucoup plus grands aujourd'hui, ce qui diminue la visibilité des caractéristiques des sites. L'incidence de la prêle et du saule sur les sites archéologiques pourrait être atténuée par l'utilisation de géotextiles et le broutage du bétail. Il y a toutefois lieu de se pencher de plus près sur ces deux méthodes avant de les adopter dans la zone étudiée.

Mots clés : végétation; Bas-Arctique; sites archéologiques; endommagement des racines; visibilité; fjord de Nuuk

Traduit pour la revue Arctic par Nicole Giguère.

\footnotetext{
${ }^{1}$ Department of Environmental Archaeology and Materials Science, National Museum of Denmark, IC Modewegsvej, DK-2800 Kgs. Lyngby, Denmark

${ }^{2}$ Corresponding author: henning.matthiesen@natmus.dk

${ }^{3}$ Center for Permafrost (CENPERM), Department of Geosciences and Natural Resource Management, University of Copenhagen, Øster Voldgade 10, DK-1350 Copenhagen K, Denmark

${ }^{4}$ Greenland National Museum and Archives, Hans Egedesvej 9, Boks 145, GL-3900 Nuuk, Greenland

(C) The Arctic Institute of North America
} 


\section{INTRODUCTION}

Archaeological sites in the Arctic represent an irreplaceable record of human history. Low temperatures, favourable moisture conditions, limited human impact, and sparse vegetation have limited the decay of material remains in many Arctic regions, which has contributed to an often extraordinary preservation of both organic and inorganic materials. The archaeological remains do not necessarily have to be deeply buried to be preserved, and most features and in some cases even artefacts are found well-preserved on the surface for centuries or millennia. This level of preservation means that archaeological remains in the Arctic are often immediately visible to the naked eye and new sites can be located during archaeological surface surveys without requiring, for example, geophysical survey, soil analysis, or destructive investigation methods such as subsurface testing or excavation.

However, environmental conditions are rapidly changing; the Arctic is warming twice as fast as the global average (IPCC, 2013) and this warming could potentially have severe consequences for the continued preservation of the archaeological remains (Hollesen et al., 2018). Several recent studies show that vegetation patterns are currently changing in Arctic and alpine areas, with shrub habitat especially increasing (Normand et al., 2013; Formica et al., 2014; Myers-Smith et al., 2015a). It is currently uncertain if these results also apply to archaeological sites, as their vegetation cover may differ from the surrounding areas due to accumulated soil nutrients (Forbes, 1996; Derry et al., 1999; Forbes et al., 2002; Fenger-Nielsen et al., 2019). Furthermore, it is unclear how a changing vegetation will ultimately influence archaeological sites in the Arctic, but the most important negative effects could include physical disturbance of cultural layers, structures, and artefacts by root perturbation (Cox et al., 2001; Crow and Moffat, 2005; Caneva et al., 2006); damage due to windthrow of large shrubs and trees (Crow and Moffat, 2005); decreased visibility and accessibility of archaeological sites (Barlindhaug et al., 2007); increased evapotranspiration and desiccation of the deposits (Mitsch and Gosselink, 2015); chemical or biological damage to artefacts through root etching and increased transport of oxygen (Crow, 2008; Tjelldén et al., 2015); and possibly higher soil temperature and increased microbial activity due to the accumulation of drifting snow (Sturm et al., 2005). The vegetation on archaeological sites may also have some positive effects, such as reduced erosion (Darwill, 1987; Gyssels et al., 2005; Caple, 2016). To our knowledge, these effects have only been discussed for archaeological sites in temperate regions and not for the Arctic, where the ongoing vegetation changes call for an urgent study of the effects.

The present study focuses on two effects from vegetation: (1) root damage to buried archaeological remains and (2) limited access and reduced visibility of the archaeological sites due to vegetation overgrowth. We identify which vegetation species are of greatest concern and what areas are most at risk within the study region. Furthermore, we evaluate if the impact from vegetation has increased significantly in recent years, if the impacts are similar on archaeological sites compared to those on surrounding areas, and if it is possible to mitigate the negative effects from the vegetation.

\section{METHODS AND STUDY REGION}

This vegetation study is a component of the REMAINS of Greenland project (Hollesen et al., 2017), in which varying threats to archaeological sites are systematically investigated and compared using a newly developed evaluation protocol (Harmsen et al., 2018). The study was conducted in the extensive fjord system near the capital city of Nuuk, where a large number of archaeological sites are found. Vegetation impacts were examined in August 2016 and August 2017 at 14 sites (Fig. 1 and Table 1), which span a climatic gradient from the outer coast with a relatively wet and cold growth season to the inner fjords and valleys adjacent to the inland ice with a drier and warmer growth season (Hollesen et al., 2019). All sites contain both ruins and concentrated subsurface deposits (middens). The sites represent cultural sequences and remains that span between ca. 4200 and 45 years before present (Harmsen et al., 2018). At most sites, the structural ruins (i.e., house features) were excavated by archaeologists from the 1930s to the 1950 s, whereas the midden deposits were generally less disturbed. Most ruins have walls made of turf reinforced by stone, and only a few structures are made with dry stone walls. Most cultural deposits have been removed from excavated ruins, but the presence of intact floor layers in many structures makes it still relevant to study potential root damage. Site visits were of different durations, allowing for detailed recording, sampling, and small test excavations at some sites, with only brief surface study at other sites.

At each site, a core area was defined (termed "cultural"), which included the structural ruins and the adjacent midden deposits. In the core area, a very distinct anthropogenic influence on the vegetation has been observed (FengerNielsen et al., 2019), which is not necessarily comparable to larger-scale studies of vegetation changes in the region (e.g., Normand et al., 2013). A surrounding reference area (termed "reference") was also noted where the anthropogenic influence was observed to be less intense. Within the cultural areas, the surfaces of middens were typically dominated by grasses and horsetail (Equisetum arvense) (Fenger-Nielsen et al., 2019), while excavated ruins and reference areas were typically dominated by shrubs. Locating the reference areas was a compromise: on the one hand, environmental conditions and settings should be similar to the core area; on the other hand, the anthropogenic influence should be less intense. Similar to other studies (Forbes, 1996; Derry et al., 1999; FengerNielsen et al., 2019), we chose reference areas that were typically 50-100 m away from the core areas, and we 


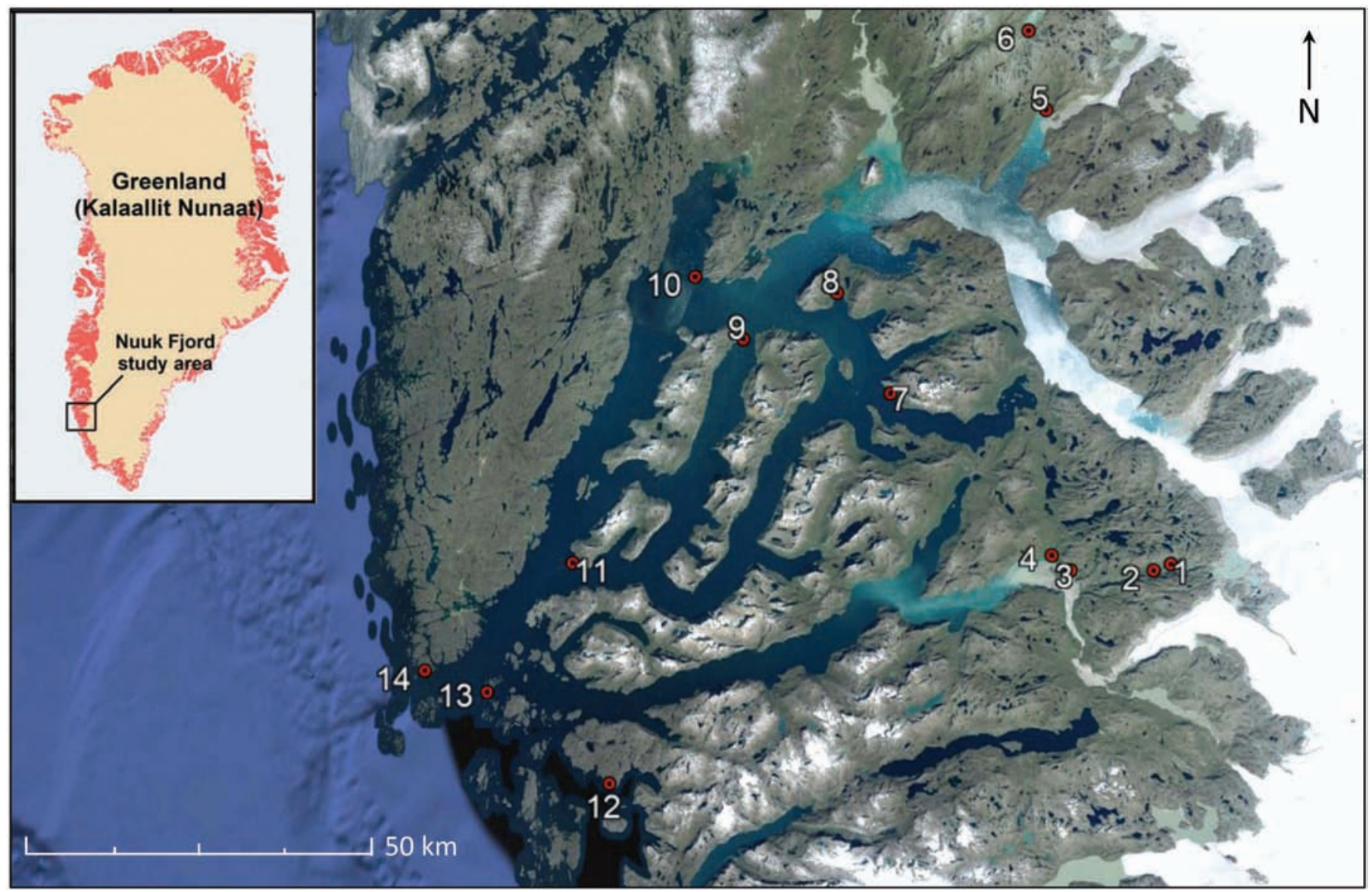

FIG. 1. Location of the archaeological sites (numbered 1 to 14) in the Nuuk Fjord study region.

avoided areas with an obvious visible impact from past human disturbance.

Vegetation was studied both above and below the ground. For the belowground studies, a total of 19 test pits $(25 \times 50 \mathrm{~cm}, 30-90 \mathrm{~cm}$ deep) were made, their depth being limited by the occurrence of either frozen soil or solid rock (Table 1). The number of test pits varied at each site but represented both cultural and reference areas with different types of vegetation. The test pits were used to register the deepest penetration of roots and thus the maximum influence depth from the vegetation. A coarse classification of roots was made, which distinguished between woody roots (typically $3-20 \mathrm{~mm}$ thick, from shrubs), rhizomes (typically $2-4 \mathrm{~mm}$ thick, from horsetail), and fine roots (typically $<1 \mathrm{~mm}$ thick, mainly from grasses). In test pits within cultural deposits, samples of bone material were taken from different depths to quantify the proportion influenced by roots, based on a visual evaluation. The influenced proportion included both bones penetrated by roots, bones with etching patterns, and bones with roots adhered to their surface. Soil samples of $100 \mathrm{~cm}^{3}$ volume were taken at $10 \mathrm{~cm}$ depth intervals to quantify the root density in nine test pits at Kilaarsarfik (Sandnæs, no. 4) covering both cultural and reference deposits. The soil samples were wet sieved ( $2 \mathrm{~mm}$ sieve), and the roots were hand sorted and divided into horsetail rhizomes, woody roots, and fine roots. For each sample, the total length of horsetail rhizomes was measured, and for all roots both the dry weight (weight after $16 \mathrm{~h}$ at $105^{\circ} \mathrm{C}$ ) and the weight after ignition (weight after $16 \mathrm{~h}$ at $450^{\circ} \mathrm{C}$ ) was determined. For some of the root samples it was difficult to remove all soil particles from the root-mat, which potentially gave a bias to the dry weight of the sample. Therefore the loss-on-ignition (i.e., dry weight minus weight after ignition) provided the best measure for determining the root organic content and root density.

For aboveground studies, surface vegetation was described at each site and the dominating species were listed and compared to notes or photos from earlier visits to the site (e.g., found in reports and documents from the archives at the national museums of Greenland and Denmark, as well as published material such as Gulløv, 1983 and Roussell, 1941). When historic photos were available, exact reproductions were made to allow an evaluation of the changes over time. Aerial photos from 1940 to 1943 (United States Army Air Force, spatial resolution ca. 2 m) were compared to modern satellite imagery (Pléiades satellite operated by National d'Etudes Spatiales, spatial resolution of $0.5 \mathrm{~m}$ ) to evaluate large-scale changes in vegetation. Special attention was given to shrubs, and the typical shrub height was noted at each site. At nine sites, samples of willow (Salix glauca) were taken in both the core area and 


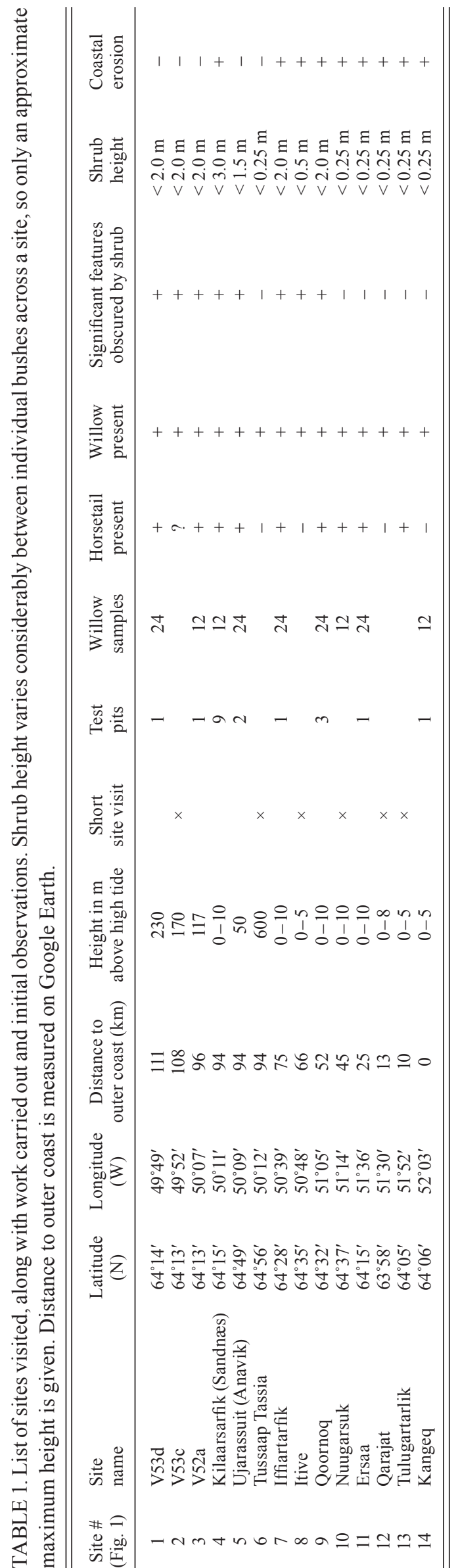

reference areas (6 or 12 samples in each area) using random sampling; that is, we did not attempt to find the oldest or largest individuals (MyersSmith et al., 2015b). For each individual sample, approximately $10 \mathrm{~cm}$ of the lowest part of the stem at the soil surface was collected. This portion was used to measure the basal stem diameter, which was determined as the mean of the maximum and minimum diameters at the soil surface.

\section{RESULTS AND DISCUSSION}

The results and discussion focus on five research questions: Is there an observable impact from vegetation on the archaeological remains? If so, what particular species are causing the most damage? Does the impact from these species vary across the study region? Have the damaging species expanded in range or size in recent years? Is it possible to mitigate or reduce the negative impact from these species?

\section{Impact from Vegetation}

Vegetation causing physical damage to standing structures is well known from archaeological sites and monuments in temperate regions (Caneva et al., 2006; Bartoli et al., 2017), where vegetation damage to ruins includes weathering forms such as biological colonisation, discoloration, flaking, and disintegration (Bartoli et al., 2017). Because ruins in this study consist of turf and unworked stone, large structural damage is more relevant than sources of weathering such as discoloration and flaking. Figure 2a shows an example from the Ujarassuit site (Anavik, no. 5), where willow growth is pushing the stones apart in a Norse stone wall. However, no architectural structures or features at the sites visited were observed to have collapsed due to the vegetation, and physical damage to standing structures is not considered to be the most critical threat in this area. In some cases, the vegetation will actually help to stabilize turf walls by limiting erosion and soil movement.

Less visible, but familiar to archaeologists, is the damage resulting from root growth in cultural deposits. Roots and rhizomes may cause both physical and chemical damage to the buried materials (Tjelldén et al., 2015). Figure $2 b$ shows an example from a midden of a bone with a protruding horsetail rhizome. Samples of bone were taken from test pits in middens at the study sites to quantify how many were affected by roots. Visual recordings showed that approximately $38 \%$ of the bone samples $(\mathrm{n}=325)$ was affected by roots, with the largest number in the upper soil layers (Fig. 3). In most cases, the roots were attached to the surface of the bones (causing visual etching on some of them); in a few cases, roots were growing through the bones and breaking them apart. Less than $10 \%$ of the sampled bones were considered heavily damaged or broken by roots, but most of these bones were still identifiable. However, the true percentage may be higher than we observed as some test pits contain an unknown number of bones that cannot be sampled because of severe degradation or dissolution. The dissolved bones are only visible as a change in colour or structure of the soil, and it is difficult to evaluate the possible impact from roots in these cases. Besides the impact on individual artefacts, roots may also disturb the cultural layers and make excavation and interpretation of archaeological contexts more difficult (Tjelldén et al., 2015). Furthermore, vegetation is also known to influence soil moisture and temperature (Aalto et al., 2013), which in turn influence the oxygen supply and degradation rate of buried organic materials (Hollesen and Matthiesen, 2015; Matthiesen et al., 2015). 

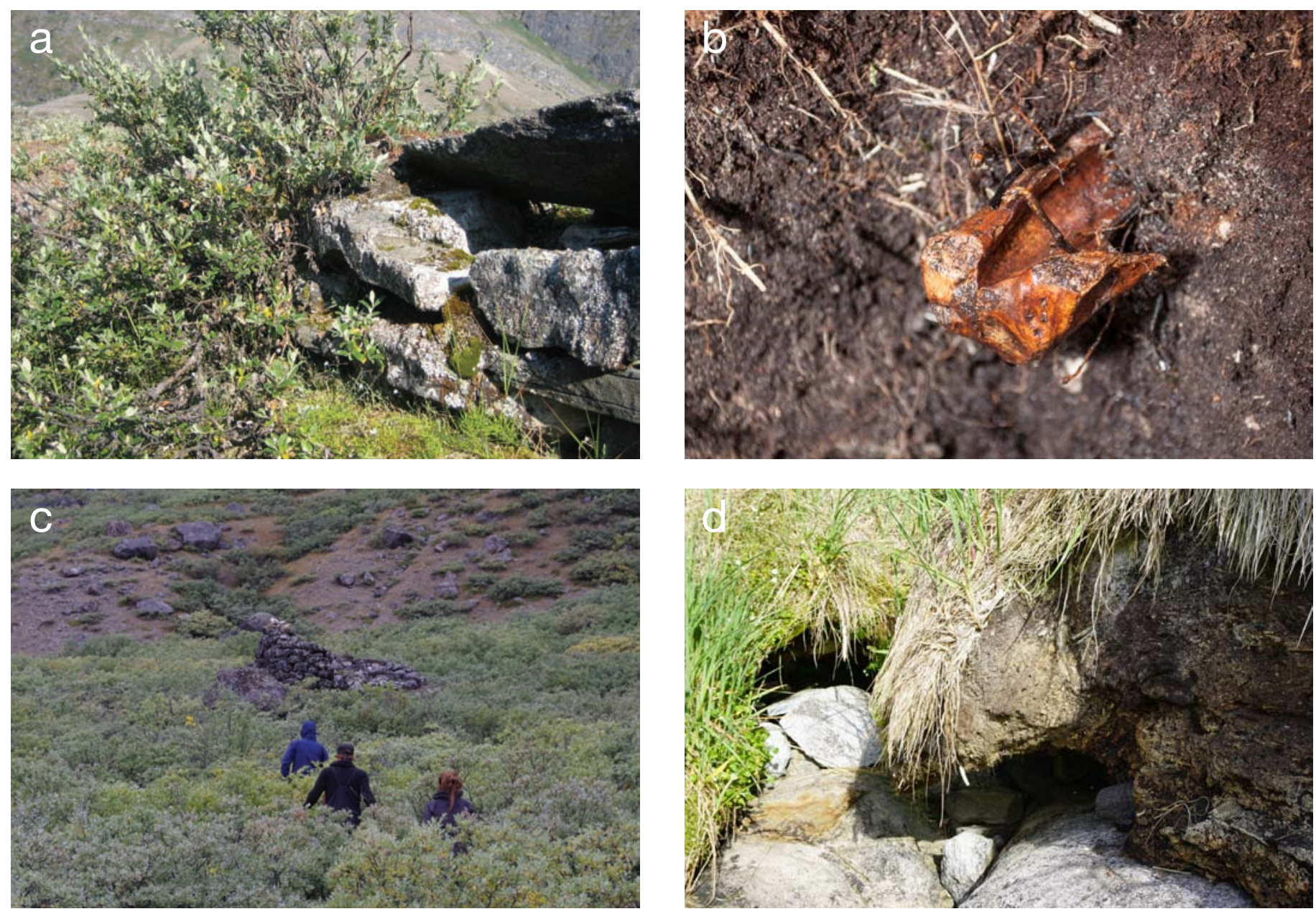

FIG. 2. Examples of impact from vegetation on the archaeological sites. a) damage to structures, b) damage to buried archaeological material, c) lack of visibility, and d) protection against erosion. Photos a, c, d by H. Matthiesen; photo b by R. Fortuna.

Extensive growth of shrubs on archaeological sites may both limit the access to the sites and make it difficult to even locate them. Reduced accessibility and visibility proved to be one of the most important impacts of vegetation on the archaeological sites assessed in this study. For instance, Figure 2c shows a Norse drying house protruding above a dense growth of shrubs. Around the drying house are several other features that are covered by shrubs and difficult to locate visually. In large parts of Greenland, archaeological remains from different cultural periods are easily discernible as aboveground features, deposits, and even artefact debris. Thus, an increase in shrub distribution and size can impede the management of sites and reduce their value as sources of public outreach and tourism. Eight of the 14 sites in this study possessed significant features currently obscured by shrubs (Table 1), while some of the remaining sites were vulnerable to decreased visibility if the shrubs increase in height.

Vegetation may also have a positive impact on archaeological sites by reducing the risk of erosion (Gyssels et al., 2005; Caple, 2016). Figure $2 \mathrm{~d}$ is from the coastal site of Kangeq (no. 14), where erosion takes place during spring tide due to a high seawater level. The photo shows part of a vertical profile left exposed after an excavation in 1969 (Gulløv, 1997). While the lower soil layers continue to erode, the topsoil is held together by a dense mat of lyme grass (Elymus mollis). This example demonstrates how vegetation may consolidate soil and decrease the threat of erosion and soil transport. This phenomenon was observed at all coastal sites (nine of the 14 sites visited; Table 1).

\section{Most Damaging Species}

The potential damage from roots depends on root depth, which determines if damage only occurs in the uppermost soil layers or continues down through the archaeological deposits. Figure 4 shows the maximum penetration depth for three different types of roots observed in 17 test pits from across seven sites. Ten of the test pits were placed in cultural deposits and seven in reference areas. The results are pooled as no significant difference in root penetration could be observed between the cultural and reference areas $(p>0.4)$. In several cases, test pit depth was limited by soil thickness or the occurrence of frozen soil; thus, some of the roots may have gone even deeper. Figure 5 shows results from quantitative measurements of the root density for the 


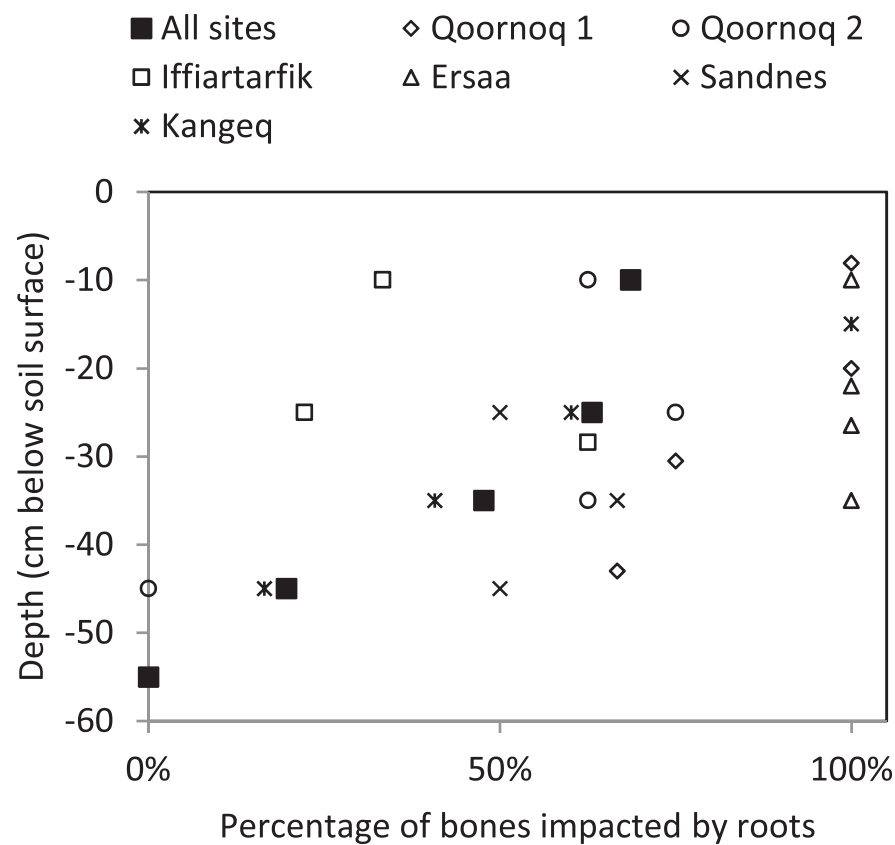

FIG. 3. Percentage of bones impacted by roots relative to depth below the soil surface. The figure shows the results from individual sites and the weighted average for all sites using depth intervals $0-20,20-30,30-40,40-50$, and $50-60 \mathrm{~cm}$. The total number (n) of bones $=325$.

three different root categories (woody roots, rhizomes, and fine roots) across nine test pits at Sandnes.

We observed that even small willow plants can have thick, woody roots, which can cause significant physical disturbance of archaeological deposits and make it difficult to excavate the topsoil (Fig. 6). However, willow roots did not appear to penetrate very deeply; root density was often high in the topsoil (Fig. 5), but at approximately $25-30 \mathrm{~cm}$ below the soil surface, the roots bend and continue horizontally. Attempts to follow some of the main roots showed that several plants could sprout from the same horizontal root. Willow roots were observed in seven of the 17 test pits, with only a single root observed to penetrate deeper to a depth of $60 \mathrm{~cm}$ below the surface. The results indicate that the damage and disturbance from willow roots can be substantial, but that it is mainly limited to the upper $30 \mathrm{~cm}$ in the study area. Still, as many archaeological sites in Greenland consist of surface features, deposits, and artefact scatters, even this shallow root activity can result in considerable damage to the archaeological record.

In contrast, horsetail is relatively small and looks innocuous aboveground, but its rhizomes extend deep into the cultural deposits where they can penetrate and disturb archaeological material. Horsetail rhizomes were observed in 10 of the 17 test pits; in most pits, the rhizomes continued downward to the bottom of the test pit (typically $80 \mathrm{~cm}$, but in some cases shallower because of the presence of rock or frozen soil). The density of rhizomes was greatest in the topsoil (up to $10 \mathrm{~g} / \mathrm{dm}^{3}$ ), but even at the $60 \mathrm{~cm}$ depth the density could be up to $1 \mathrm{~g} / \mathrm{dm}^{3}$ (Fig. 5), which corresponds to a horsetail rhizome more than $1 \mathrm{~m}$ long within a soil

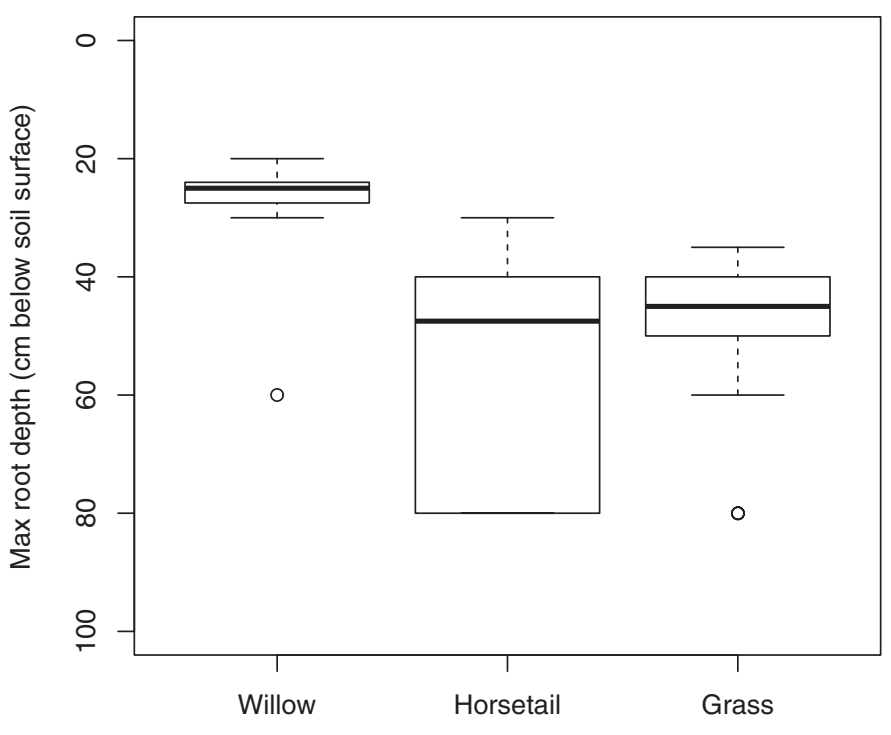

FIG. 4. Boxplot showing the maximum root depths of different species as measured in 17 test pits across seven sites (thick line shows median value, box shows 1st and 3rd quartile, whiskers show minimum and maximum values for the 17 pits, circles show possible outliers).

volume of $1 \mathrm{dm}^{3}$. Damage from horsetail is observed at archaeological sites in temperate regions (Gregory and Matthiesen, 2012); apart from the physical damage to archaeological materials, rhizomes may also transport oxygen down into otherwise anoxic deposits stimulating chemical and microbial degradation (Kutschera et al., 1992; Tjelldén et al., 2015).

The dominating grasses in the core areas of the study sites were lyme grass and bluejoint (Calamagrostis canadensis), and at a single site, Arctic bluegrass (Poa arctica). The grasses had fine roots that penetrated deeply into the cultural deposits, in one case down to $80 \mathrm{~cm}$ below the soil surface. Their root mass was similar to the horsetail rhizomes (Fig. 5), but the fine roots from grasses were observed as less detrimental to the archaeological deposits since they cause less physical disturbance to stratigraphy and artefacts. Obviously, grasses can also influence soil moisture content and lead to drying out of the cultural deposits, but generally they are considered as the least damaging vegetation type (Darwill, 1987). In the topsoil, the density of grass roots can be high and help deter erosion (Fig. 2d) so removal of all vegetation would not be beneficial for the archaeological sites.

Shrubs (especially willow) caused the main problems aboveground at the sites investigated. Willow reduced the visibility of sites (Fig. 2c) and in some cases appeared to influence feature integrity, such as walls and standing structures (Fig. 2a). It had significant negative impact on eight out of the 14 sites visited (Table 1).

In summary, horsetail and willow are considered the two most damaging species at the study sites investigated in this Low Arctic region. They were also among the most abundant species, as willow was observed at all 14 sites and horsetail at nine out of the 14 sites. 

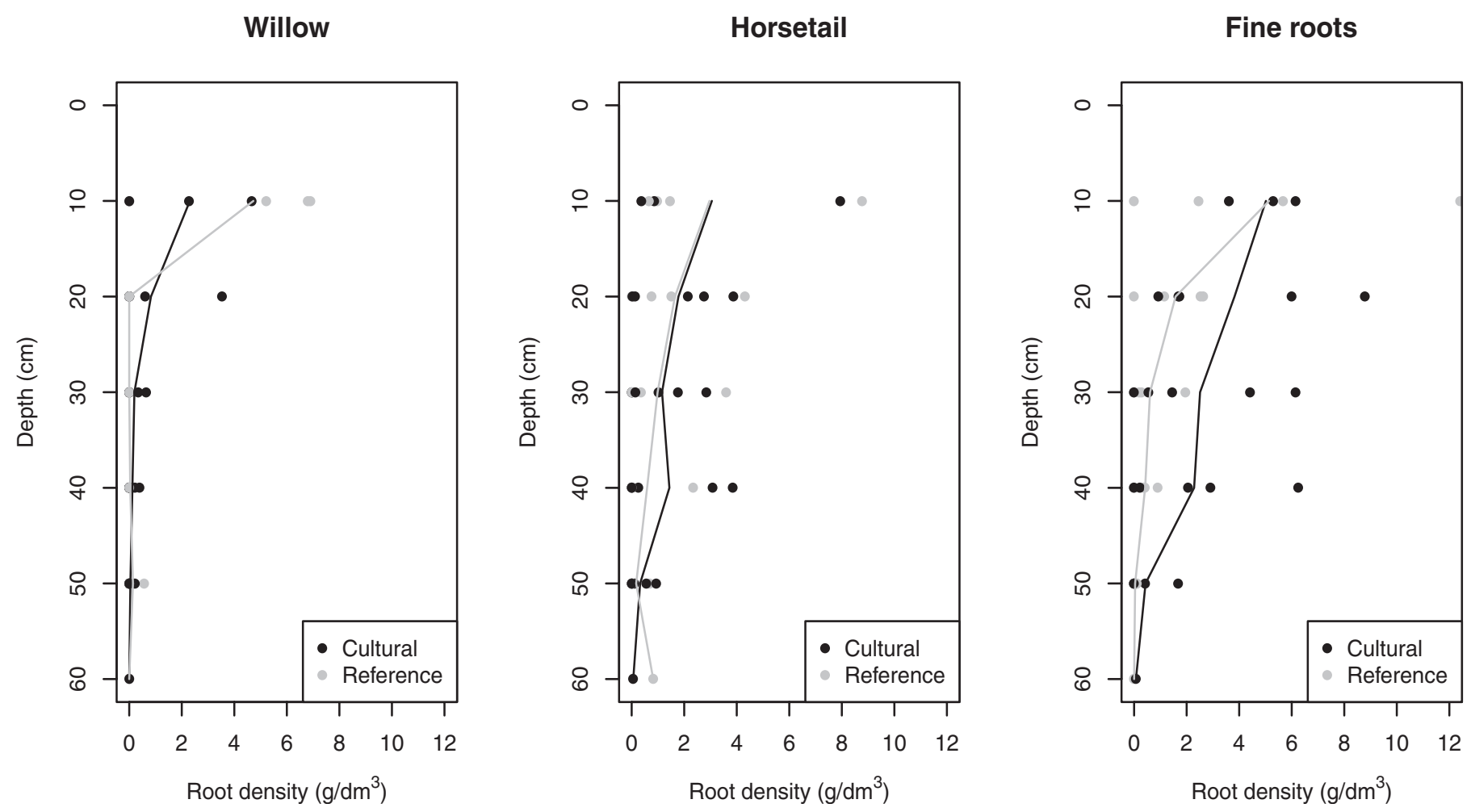

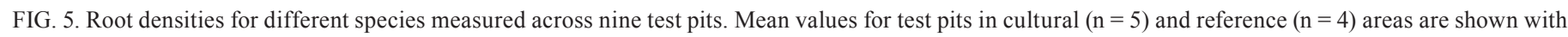
black and grey lines, respectively.

\section{Variation across Study Region}

The study region represents a climatic gradient stretching from the outer coast to the inner fjords with a variety of environmental conditions (Hollesen et al., 2019). Within each study site different microenvironments and soil conditions are present that may influence the vegetation (Fenger-Nielsen et al., 2019). It was therefore necessary to evaluate if vegetation patterns and effects on the archaeology were similar or varied within and between sites.

Figure 3 illustrates the proportions of bone affected by roots at different depths within six test pits across five sites. Chi-square tests show that the proportion of impacted bones varies significantly with depth $(p<0.001)$, between sites $(p<0.001)$ and within sites (as illustrated by the two test pits at Qoornoq (no. 9), $p=0.03$ ). The variation with depth is probably a result of variations in root densities (Fig. 5) where the highest root densities are found in the upper $50 \mathrm{~cm}$ of the soil. The variation between sites showed no discernible pattern; for example, the nine sites with horsetail included both coastal and inland sites (Table 1). This widespread distribution is supported by vegetation maps published by Fredskild (1996), which indicate that root damage from horsetail may occur throughout the whole study region. Differences in root density between cultural deposits and reference areas (Fig. 5) were not significant for horsetail and willow $(p>0.6)$, but the density of fine roots was higher in the cultural deposits $(p=0.03)$, as was also noted by Fenger-Nielsen et al. (2019).
To investigate the impacts from vegetation aboveground, we measured basal stem diameter of willow at nine of the study sites (Fig. 7). Analysis of variance (ANOVA) showed a significant difference between sites $(p<0.001)$, with basal stem diameters generally smaller along the coast and larger as one moves inland. This difference corresponds to the fact that shrubs generally grow taller at inland sites (Table 1) so it is mainly sites in the inner fjords (east of ca. $51^{\circ} \mathrm{W}$ ) that are currently visually impacted by shrubs. No single trend in stem diameter was found between cultural areas and reference areas in the study region. Looking at individual sites, we found a significant difference at V53d (no. $1 ; p=0.03$ ), V52a (no. $3 ; p=0.004$ ) and Qoornoq (no. $9 ; p=0.02$ ), but the remaining sites showed no significant difference $(p=0.10-0.85)$. More distinct differences might have been found if the reference areas had been placed farther away from the core areas.

During the site visits, we observed the long-term effects of prior archaeological activities. At many of the sites excavated in the 1930s to 1950 s, there was no backfilling of the ruins or trenches after excavation. As a result, excavated features and rooms with standing walls appear to have provided sheltered habitats favourable for plant growth, especially shrub vegetation. With no backfilled soil to protect intact features and layers from root activity, the potential for damage to shallow subsurface archaeological remains is considerable, which serves as a warning that backfilling should always be carried out after excavation. Our results indicate that the numerous studies on shrub expansion at a regional scale (e.g., Normand et al., 2013) 

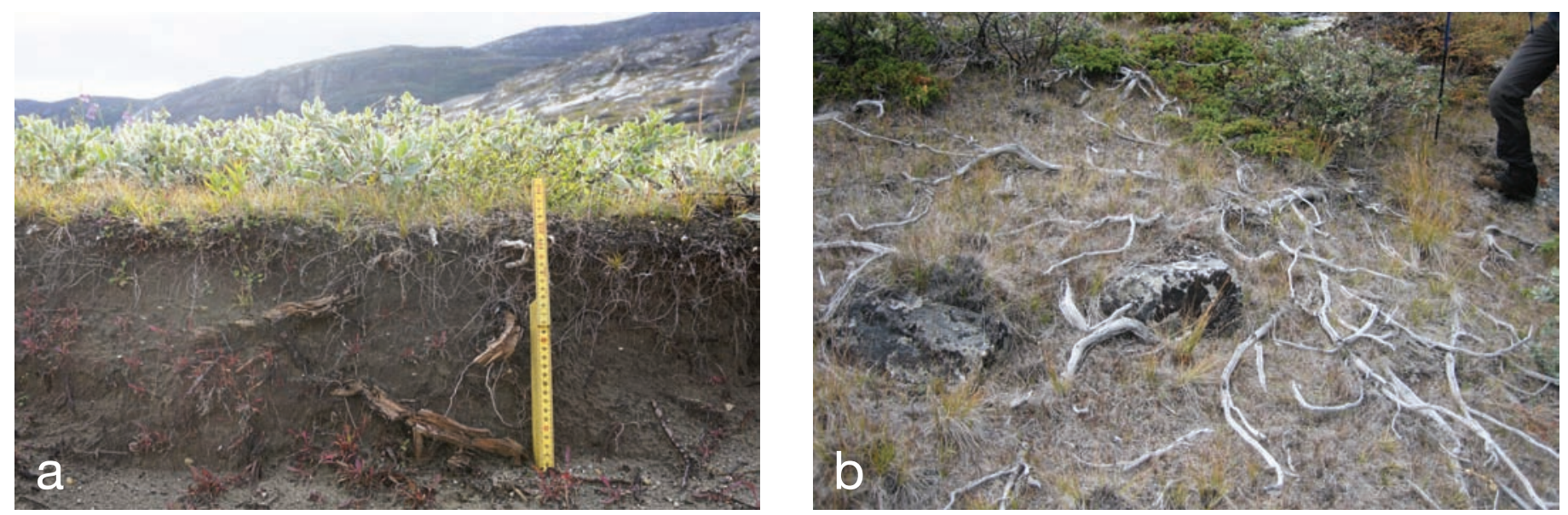

FIG. 6. a) Even small willows can have relatively thick roots (scale $35 \mathrm{~cm}$ ). b) The willows can be connected by a dense network of roots lying just under the soil surface, here exposed due to soil erosion on a steep slope. Photos: H. Matthiesen.

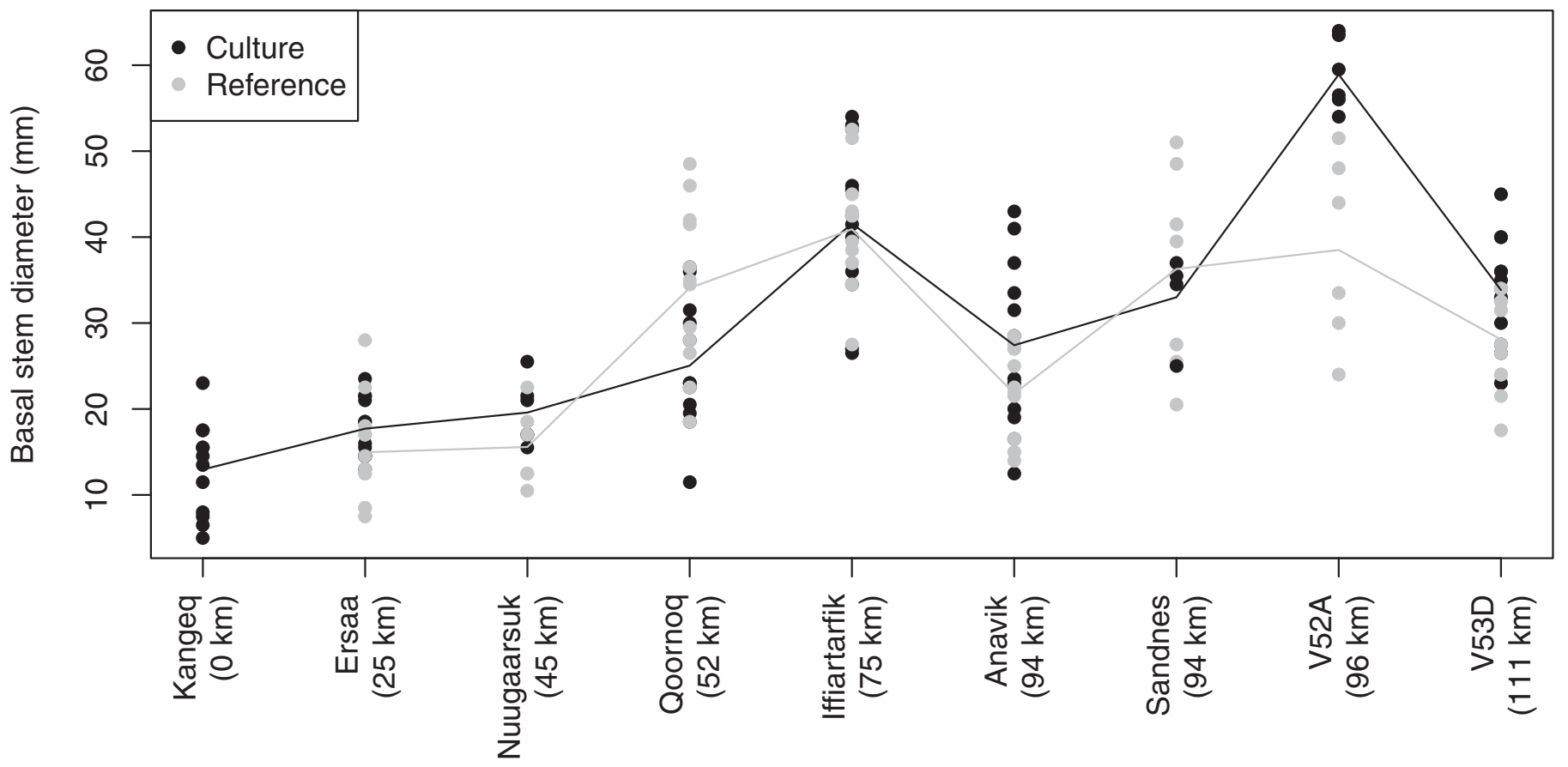

FIG. 7. Basal willow stem diameters measured at the soil surface. Sites are arranged in order of increasing distance to the coast, going from west to east. The number of samples (n) varies between 6 and 12 for each cultural and reference area. At Kangeq, no willows were found on reference areas. Mean values for willows on cultural and reference areas are shown with black and grey lines, respectively.

should be used with caution to predict what is happening at archaeological sites, which are highly influenced by human activities.

\section{Recent Changes in Shrub Growth}

Regional studies on shrub growth exist for the Nuuk fjord area (Nielsen et al., 2017), but we need to look specifically at the archaeological sites to evaluate if these have experienced an increase in shrub growth. Development over time is addressed here by comparing historic and new photos and descriptions of the study sites. Site V53c (no. 2) was photographed in 1937 during archaeological fieldwork (Roussell, 1941) and again in 2016 during this study
(Fig. 8). The photographs indicate a significant increase in shrub size over the last 79 years at this inland site. At two other inland sites, V53d (no. 1) and Anavik (no. 5), historic photographs from the 1930s also show fewer or smaller shrubs than observed today. At the sites Iffiartarfik (no. 7), Ersaa (no. 11) and Qarajat (no. 12), reports from the 1940s and 1950s mention the presence of willow, but provide no details about the size or exact distribution (Gulløv, 1983). Although comparative photos are very illustrative, it is difficult to quantify shrub expansion by this method, since the historic photos were not recorded systematically and not with the intended purpose of documenting shrub growth.

Establishing a time series of aerial and satellite imagery is an alternative method that has shown great potential 

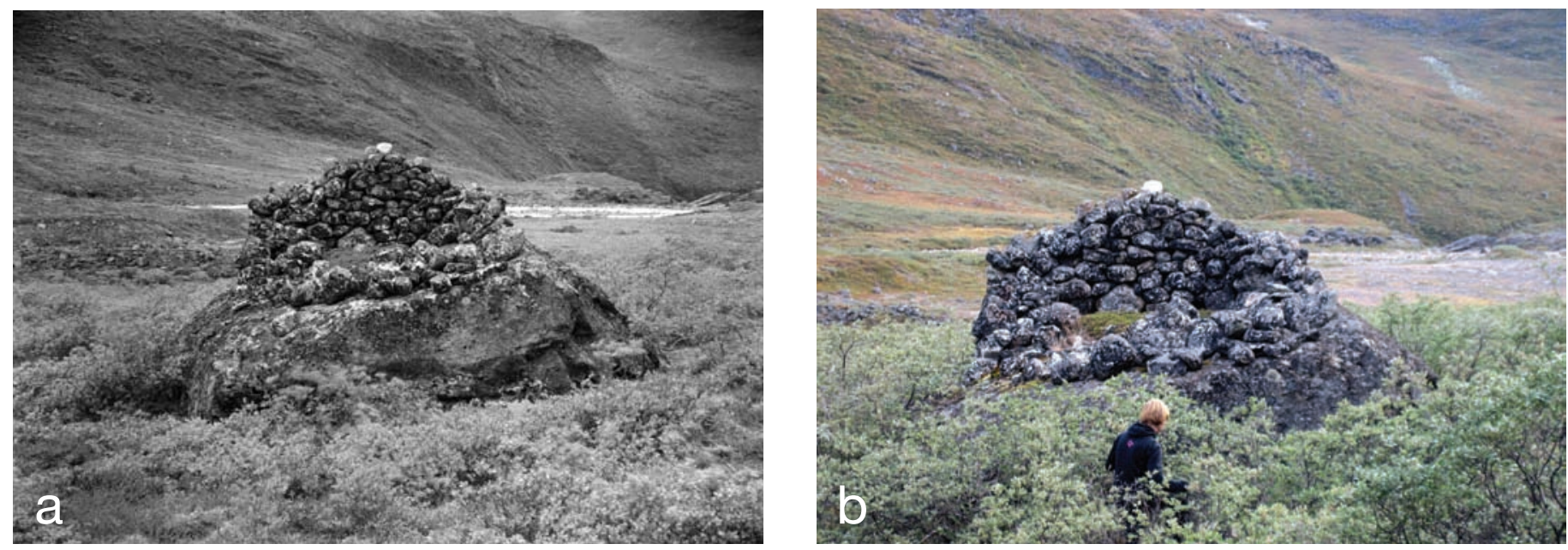

FIG. 8. Stone structure at Norse farm V53c in Austmannadalen photographed by A. Rousell in 1937 (a) and by H. Matthiesen in 2016 (b). Shrub size has increased significantly over the last 79 years at this inland site.
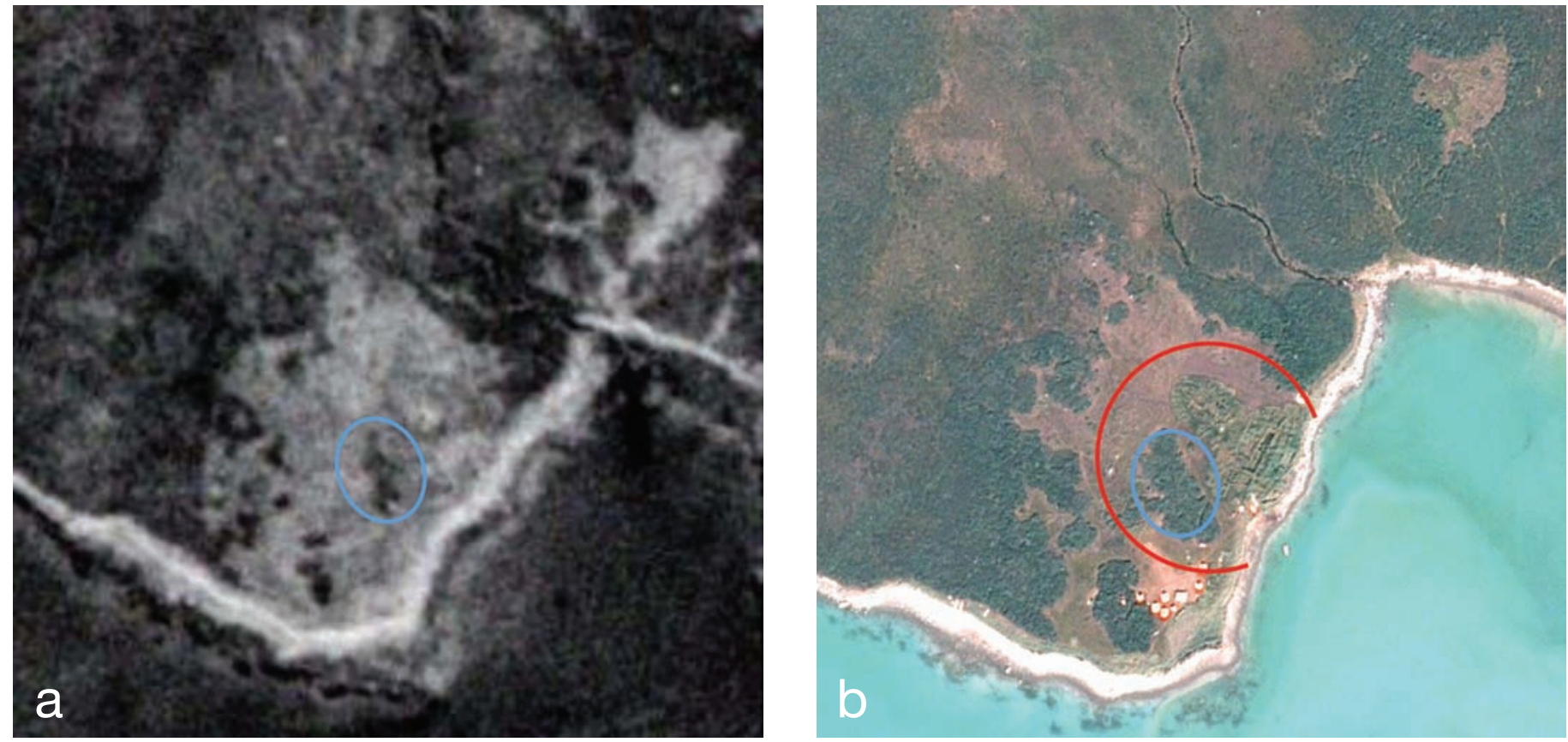

FIG. 9. (a) Aerial image from 1940 compared to (b) a VHR satellite image (Pléiades) from 2016 of Kilaarsarfik (Sandnæs, no. 4), approximately 200 m wide. Shrubs are visible as dark grey colors in the aerial image from 1940. The approximate outline of the archaeological site (buildings and midden) is indicated by the red line on the satellite image, and an example of shrub expansion is visible inside the blue circle. The buildings were excavated between 1930 and 1932 (Roussell, 1936).

for documenting temporal changes in vegetation in the Arctic (Sturm et al., 2001; Barlindhaug et al., 2007; Formica et al., 2014). At present, only a few aerial image time series with sufficient spatial resolution are available for Greenland. Figure 9 shows an aerial image from 1940 of Kilaarsarfik (Sandnes, no 4) juxtaposed against a very high-resolution (VHR) satellite image from 2016. At this location, comparative imagery indicates local expansion in shrub vegetation at the archaeological core area, possibly as a result of archaeological excavations in 1930-32, when ruins were excavated without backfilling (Roussell, 1936). However, in general, the changes are only small as shrubs were already abundant in the study region in the 1940s.
Thus, within this Low Arctic study region, it is perhaps more interesting to see if the shrubs have increased in height, making the archaeological sites and features less visible, which is best observed from ground photos.

In summary, photos from previous site visits show an increase in willow size at three of the archaeological sites in the inner fjords since the 1930s, while it is more difficult to find evidence of changes taking place at sites in the outer fjords. We have not been able to determine if horsetail, which is found throughout Greenland (Fredskild, 1996), has become more frequent on the archaeological sites in the study region in recent years. 


\section{Mitigation of Negative Impacts}

There are numerous ways to influence vegetation, such as livestock grazing, shredding, mowing, use of coverage and herbicides, but not all these methods are suited to the protection of archaeological sites in the Arctic. As a first initiative, backfilling or reburial of previously excavated ruins to limit the exposure and root damage could be recommended (Stanley-Price et al., 2004), although the logistics required would be costly in Greenland.

Horsetail is recognised as a problem in other regions, such as at the archaeological site of Nydam in Denmark, where rhizomes penetrated and destroyed wooden artefacts. Gregory and Matthiesen (2012) found that covering the Nydam site with geotextile efficiently limited the growth of horsetail, but allowed other vegetation to become re-established on top of the geotextile within a few years. Under Arctic conditions, it will probably take longer for vegetation to re-establish, but using geotextile could be tested at a few sites now under severe threat from horsetail growth. By providing an extra physical barrier, geotextile may enhance the effects of backfilling excavated ruins and features.

Since the distribution and growth of willow is influenced by grazing, it may be possible to use sheep, for example, to mitigate willow growth at archaeological sites. However, besides the need for winter stabling and feeding of the sheep, landscape responses can be complex and need to be monitored. For example, in a study from Norway, Speed et al. (2013) demonstrated that at high elevations the presence of sheep reduced shrub expansion, while the opposite was found at lower elevations. Furthermore, it is necessary to ensure that the sheep (or other grazing animals) do not contribute to erosion at the sites or cause direct damage to archaeological features (Evans, 1997). At present, sheep are common in South Greenland, $450 \mathrm{~km}$ south of the study area, where they have caused erosion at several Norse sites. In 2018, a sheep farm was established in the Nuuk fjord area east of Iffiartarfik (no. 7) (Fig. 1), and a small population of feral sheep from a sheep farming experiment in the 1960s survive in the southeastern part of the study area. At present, the feral sheep have only very local impact on the vegetation, but it suggests that sheep could potentially play a part in future vegetation management under controlled conditions.

\section{CONCLUSION}

We observed that in our study area in the Nuuk fjord system vegetation has an impact on archaeological sites both above and below the ground. Belowground, roots and rhizomes were observed to influence archaeological materials as demonstrated in six test pits, where approximately $38 \%$ of bone samples were impacted by roots. Horsetail is especially problematic because of its deep penetrating rhizomes and frequent occurrence at archaeological sites across the study area. Willow roots, which are very thick and can form a dense horizontal network, may also disturb archaeological deposits. However, in the study area, these networks generally only penetrate to a depth of approximately $30 \mathrm{~cm}$ and thus mainly influence the upper and shallow cultural deposits. Aboveground, willow shrubs were observed to be problematic especially in the inner fjords and valleys where willows grow so high that the archaeological sites are less visible and less accessible, which affects both heritage management and tourism potential. Comparisons between historic and recent photos indicate that willows have increased in height at some of the archaeological sites in the inner fjords since the 1930s, but this is not necessarily a general rule for all sites in the area. Increased willow growth is especially observed in excavated ruins that were not backfilled. A few mitigation methods are presented that may help control the impact from vegetation. We suggest that further comparative studies should be carried out in other parts of the Arctic in order to evaluate if horsetail and willow are the only problematic species and if their root penetration depths and growth patterns are similar in other areas.

\section{ACKNOWLEDGEMENTS}

We gratefully acknowledge financial support from VELUX FONDEN (33813). Nanna Bjerregaard Pedersen and Anne Marie Høier Eriksen are acknowledged for sampling of willow, Emil Alexander Sherman Andersen for characterization of vegetation, Helle Holbek for root analyses, and Peter Steen Henriksen for comments on the manuscript. Finally, we thank three anonymous reviewers for providing useful comments that led to improvement of the manuscript.

\section{REFERENCE}

Aalto, J., le Roux, P.C., and Luoto, M. 2013. Vegetation mediates soil temperature and moisture in Arctic-alpine environments. Arctic, Antarctic, and Alpine Research 45(4):429-439.

https://doi.org/10.1657/1938-4246-45.4.429

Barlindhaug, S., Holm-Olsen, I.M., and Tømmervik, H. 2007. Monitoring archaeological sites in a changing landscape - using multitemporal satellite remote sensing as an 'early warning' method for detecting regrowth processes. Archaeological Prospection 14(4):231-244.

https://doi.org/10.1002/arp.307

Bartoli, F., Romiti, F., and Caneva, G. 2017. Aggressiveness of Hedera helix L. growing on monuments: Evaluation in Roman archaeological sites and guidelines for a general methodological approach. Plant Biosystems 151(5):866-877.

https://doi.org/10.1080/11263504.2016.1218969 
Caneva, G., Ceschin, S., and De Marco, G. 2006. Mapping the risk of damage from tree roots for the conservation of archaeological sites: The case of the Domus Aurea, Rome. Conservation and Management of Archaeological Sites 7(3):163-170. https://doi.org/10.1179/135050306793137403

Caple, C., ed. 2016. Preservation of archaeological remains in situ. London: Routledge.

Cox, M., Earwood, C., Jones, E.B.G., Jones, J., Straker, V., Robinson, M., Tibbett, M., and West, S. 2001. An assessment of the impact of trees upon archaeology within a relict wetland. Journal of Archaeological Science 28(10):1069-1084. https://doi.org/10.1006/jasc.2000.0642

Crow, P. 2008. Mineral weathering in forest soils and its relevance to the preservation of the buried archaeological resource. Journal of Archaeological Science 35(8):2262 - 2273. https://doi.org/10.1016/j.jas.2008.02.008

Crow, P., and Moffat, A.J. 2005. The management of the archaeological resource in UK wooded landscapes: An environmental perspective. Conservation and Management of Archaeological Sites 7(2):103-116. https://doi.org/10.1179/135050305793137512

Darvill, T. 1987. Ancient monuments in the countryside: An archaeological management review. London: English Heritage.

Derry, A.M., Kevan, P.G., and Rowley, S.D.M. 1999. Soil nutrients and vegetation characteristics of a Dorset/Thule site in the Canadian Arctic. Arctic 52(2):204-213. https://doi.org/10.14430/arctic923

Evans, R. 1997. Soil erosion in the UK initiated by grazing animals: A need for a national survey. Applied Geography 17(2):127-141. https://doi.org/10.1016/S0143-6228(97)00002-7

Fenger-Nielsen, R., Hollesen, J., Matthiesen, H., Andersen, E.A.S., Westergaard-Nielsen, A., Harmsen, H., Michelsen, A., and Elberling, B. 2019. Footprints from the past: The influence of past human activities on vegetation and soil across five archaeological sites in Greenland. Science of the Total Environment 654:895-905. https://doi.org/10.1016/j.scitotenv.2018.11.018

Forbes, B.C. 1996. Plant communities of archaeological sites, abandoned dwellings, and trampled tundra in the eastern Canadian Arctic: A multivariate analysis. Arctic 49(2):141 - 154. https://doi.org/10.14430/arctic1192

Forbes, B.C., Ebersole, J.J., and Strandberg, B. 2002. Anthropogenic disturbance and patch dynamics in circumpolar Arctic ecosystems. Conservation Biology 15(4):954-969. https://doi.org/10.1046/j.1523-1739.2001.015004954.x

Formica, A., Farrer, E.C., Ashton, I.W., and Suding, K.N. 2014. Shrub expansion over the past 62 years in Rocky Mountain alpine tundra: Possible causes and consequences. Arctic, Antarctic, and Alpine Research 46(3):616-631. https://doi.org/10.1657/1938-4246-46.3.616

Fredskild, B. 1996. A phytogeographical study of the vascular plants of West Greenland $\left(62^{\circ} 20^{\prime}-74^{\circ} 00^{\prime} \mathrm{N}\right)$. Meddelelser om Grønland 304, Bioscience 45. 157 p.
Gregory, D., and Matthiesen, H. 2012. Nydam Mose: In situ preservation at work. Conservation and Management of Archaeological Sites 14(1-4):479-486. https://doi.org/10.1179/1350503312Z.00000000041

Gulløv, H.C. 1983. Fortidsminder i Nuuk kommune-inuitkulturens bopladser [Ancient monuments in Nuuk municipality-Inuit culture settlements]. Nuuk: Kalaallit Nunaata katersugaasivia \& Nationalmuseet.

- 1997. From middle ages to colonial times. Archaeological and ethnohistorical studies of the Thule culture in South West Greenland 1300-1800 AD. Monographs on Greenland, Man \& Society 23. $501 \mathrm{p}$.

Gyssels, G., Poesen, J., Bochet, E., and Li, Y. 2005. Impact of plant roots on the resistance of soils to erosion by water: A review. Progress in Physical Geography: Earth and Environment 29(2):189-217. https://doi.org/10.1191/0309133305pp443ra

Harmsen, H., Hollesen, J., Madsen, C.K., Albrechtsen, B., Myrup, M., and Matthiesen, H. 2018. A ticking clock? Preservation and management of Greenland's archaeological heritage in the 21st century. Conservation and Management of Archaeological Sites 20(4):175-198. https://doi.org/10.1080/13505033.2018.1513303

Hollesen, J., and Matthiesen, H. 2015. The influence of soil moisture, temperature and oxygen on the oxic decay of organic archaeological deposits. Archaeometry 57(2):362 - 377. https://doi.org/10.1111/arcm.12094

Hollesen, J., Matthiesen, H., Madsen, C.K., Albrechtsen, B., Kroon, A., and Elberling, B. 2017. Climate change and the preservation of archaeological sites in Greenland. In: Dawson, T., Nimura, C., Lôpez-Romero, E., and Daire, M.-Y., eds. Public archaeology and climate change. Oxford: Oxbow Books. 90-99. https://doi.org/10.2307/j.ctvh1dp4n.14

Hollesen, J., Callanan, M., Dawson, T., Fenger-Nielsen, R., Friesen, T.M., Jensen, A.M., Markham, A., Martens, V.V., Pitulko, V.V., and Rockman, M. 2018. Climate change and the deteriorating archaeological and environmental archives of the Arctic. Antiquity 92(363):573-586.

https://doi.org/10.15184/aqy.2018.8

Hollesen, J., Matthiesen, H., Fenger-Nielsen, R., Abermann, J., Westergaard-Nielsen, A., and Elberling, B. 2019. Predicting the loss of organic archaeological deposits at a regional scale in Greenland. Scientific Reports 9: Article 9097. https://doi.org/10.1038/s41598-019-45200-4

IPCC (Intergovernmental Panel on Climate Change). 2013. Climate change 2013: The physical science basis. Contribution of Working Group I to the Fifth Assessment Report of the Intergovernmental Panel on Climate Change. Cambridge and New York: Cambridge University Press.

Kutschera, L., Lichtenegger, E., and Sobotik, M. 1992. Wurzelatlas Mitteleuropäischer Grünlandpflanzen [Root atlas of Central European grassland plants]. Band 2. Pteridophyta und Dicotyledoneae (Magnoliopsida). Stuttgart: Gustav Fischer Verlag. 
Matthiesen, H., Hollesen, J., Dunlop, R., Seither, A., and de Beer, J. 2015. In situ measurements of oxygen dynamics in unsaturated archaeological deposits. Archaeometry 57(6):1078-1094. https://doi.org/10.1111/arcm.12148

Mitsch, W.J., and Gosselink, J.G. 2015. Wetlands, 5 ed. Hoboken, New Jersey: John Wiley \& Sons.

Myers-Smith, I.H., Elmendorf, S.C., Beck, P.S.A., Wilmking, M., Hallinger, M., Blok, D., Tape, K.D., et al. 2015a. Climate sensitivity of shrub growth across the tundra biome. Nature Climate Change 5:887-891. https://doi.org/10.1038/nclimate2697

Myers-Smith, I.H., Hallinger, M., Blok, D., Sass-Klaassen, U., Rayback, S.A., Weijers, S., Trant, A.J., et al. 2015b. Methods for measuring Arctic and alpine shrub growth: A review. Earth-Science Reviews 140:1-13. https://doi.org/10.1016/j.earscirev.2014.10.004

Nielsen, S.S., von Arx, G., Damgaard, C.F., Abermann, J., Buchwal, A., Büntgen, U., Treier, U.A., Barfod, A.S., and Normand, S. 2017. Xylem anatomical trait variability provides insight on the climate-growth relationship of Betula nana in western Greenland. Arctic, Antarctic, and Alpine Research 49(3):359-371. https://doi.org/10.1657/AAAR0016-041

Normand, S., Randin, C., Ohlemüller, R., Bay, C., Høye, T.T., Kjær, E.D., Körner, C., et al. 2013. A greener Greenland? Climatic potential and long-term constraints on future expansions of trees and shrubs. Philosophical Transactions of the Royal Society B 368: 20120479.

https://doi.org/10.1098/rstb.2012.0479
Roussell, A. 1936. Sandnes and the neighbouring farms. Meddelelser om Grønland 88. 219 p.

- 1941. Farms and churches in the mediaeval Norse settlements of Greenland. Meddelelser om Grønland 89. 354 p.

Speed, J.D.M., Austrheim, G., Hester, A.J., and Mysterud, A. 2013. The response of alpine Salix shrubs to long-term browsing varies with elevation and herbivore density. Arctic, Antarctic, and Alpine Research 45(4):584-593.

https://doi.org/10.1657/1938-4246-45.4.584

Stanley-Price, N.P., Burch, R., and Matero, F.G.E. 2004. Reburial of archaeological sites: A colloquium organized by the Getty Conservation Institute, the National Park Service (Intermountain Region) and ICCROM 17-21 March 2003, Santa Fe, New Mexico. Conservation and Management of Archaeological Sites 6(3-4).

Sturm, M., Racine, C., and Tape, K. 2001. Climate change. Increasing shrub abundance in the Arctic. Nature 411:546-547.

Sturm, M., Schimel, J., Michaelson, G., Welker, J.M., Oberbauer, S.F., Liston, G.E., Fahnestock, J., and Romanovsky, V.E. 2005. Winter biological processes could help convert Arctic tundra to shrubland. BioScience 55(1):17-26. https://doi.org/10.1641/0006-3568(2005)055[0017:WBPCHC]2 .0.CO;2

Tjelldén, A.K.E., Kristiansen, S.M., Matthiesen, H., and Pedersen, O. 2015. Impact of roots and rhizomes on wetland archaeology: A review. Conservation and Management of Archaeological Sites 17(4):370-391. https://doi.org/10.1080/13505033.2016.1175909 